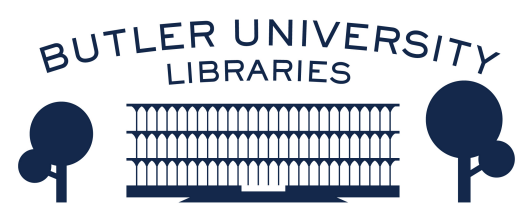

Journal of Hindu-Christian Studies

Volume 23

Article 7

January 2010

\title{
"He is our master": Jesus in the Thought of Swami Prabhupada
}

Ravi M. Gupta

Follow this and additional works at: https://digitalcommons.butler.edu/jhcs

Part of the Religion Commons

\section{Recommended Citation}

Gupta, Ravi M. (2010) "'He is our master": Jesus in the Thought of Swami Prabhupada," Journal of HinduChristian Studies: Vol. 23, Article 7.

Available at: https://doi.org/10.7825/2164-6279.1459

The Journal of Hindu-Christian Studies is a publication of the Society for Hindu-Christian Studies. The digital version is made available by Digital Commons @ Butler University. For questions about the Journal or the Society, please contact cbauman@butler.edu. For more information about Digital Commons @ Butler University, please contact digitalscholarship@butler.edu. 


\title{
"He is our master": Jesus in the Thought of Swami Prabhupāda
}

\author{
Ravi M. Gupta \\ College of William and Mary
}

NOW that steam, electricity, and the printing press have brought into closer communication the different races that inhabit the earth, and have expanded the minds of men, tending to dispel the illusion that God Almighty especially favours any particular people, it is time to proclaim to the world, that if a messenger of God appeared in Judea about nineteen hundred years ago, it is no less true that a messenger from the same God appeared in the quiet town of Navadweep (popularly known as Nadia) in Bengal, some fifteen centuries later. The former is known by the name of Jesus Christ; the latter is known in India by the name of Sree Gauranga, Sree. Krishna Chaitanya, and several other names. If wonders attended Jesus, so also they attended Sree Gauranga of Nadia.

The Christians have conferred an inestimable obligation upon those Hindus whose faith has been affected by Western materialism, by presenting Christ to them; and they, as a grateful return, are anxious to present Sree Krishna and Sree Gauranga to the people of the West. (10).

So begins Shishir Kumar Ghose's lengthy biography of Caitanya, published at the turn of the twentieth century. Ghose is not alone in drawing parallels between Caitanya and Jesus; since at least the mid-nineteenth century, numerous Bengali thinkers, articulating a Hindu response to colonial Christianity, felt a strong resonance between the lives and character of these two teachers. Keshub Chander Sen, a religious reformer of the Bengal renaissance, mentions Caitanya as the Hindu teacher who embodies the presence of Christ (28). A decade later, Kshitish Chandra Chakravarti repeatedly makes use of Christian terminology to describe Chaitanya and compares the Nativity scene to events in Chaitanya's life (7). This use of language and imagery does not go unnoticed back in Britain; Jim Morrison, in his Robertson lectures at the University of Glasgow, calls attention to "the new power of Christ's personality" and credits Jesus for the resurgence of Chaitanya's movement: "A Christ-like man, indeed, in many ways, Chaitanya was, and the increased acquaintance of educated Bengal with Jesus Christ naturally brought Chaitanya to the front" (199). Finally, in one of the earliest Western academic studies of the Chaitanya movement, Melville Kennedy devotes an entire section to outlining the relation between Chaitanya and Christianity.

Joining this long line of Bengali thinkers was A.C. Bhaktivedanta Swami Prabhupāda (1896-1977) in the mid-twentieth century, the founder of the International Society for Krishna Consciousness (ISKCON), known also as the Hare Krishna movement. ${ }^{1}$ Prabhupāda's background was similar to many of his contemporary Bengali bhadralok: he grew up in a devout (Caitanya) Vaiṣnava family, received an English-medium education at Calcutta's Scottish Church College, and joined the

Ravi M. Gupta is Assistant Professor of Religious Studies at The College of William and Mary in Williamsburg, Virginia. He holds a doctoral degree from the University of Oxford and was formerly a Junior Research Fellow at Linacre College, Oxford. He has taught a variety of courses in Hinduism and World Religions, and is the recipient of the David Hughes award for excellence in teaching. Gupta is the author of The Chaitanya Vaishnava Vedanta of Jiva Gosvami (Routledge, 2007) as well as several articles in academic journals. He is currently working with Dr. Kenneth Valpey on an abridged translation of the Bhagavata Purana, to be published by Columbia University Press. 
movement for India's independence, eventually refusing his degree in protest of the British. At present we know little of Prabhupāda's early education in Christianity, other than the several references he makes to his theologian professors at Scottish Church College and their views of Hinduism. ${ }^{2}$ Nevertheless, throughout his life Prabhupāda developed and frequently articulated a response to his encounter with Christianity. What makes Prabhupāda's response especially noteworthy is that it occurred in the context of a missionary movement in the West. At the request of his guru, Prabhupāda travelled to the United States in 1965, at the age of 70 , and opened his first center in Manhattan. The Hare Krishna movement experienced tremendous growth in the decade that followed, and he frequently circled the globe visiting ISKCON's centers and teaching his disciples. ${ }^{3}$ Prabhupāda's response to Christianity is worthy of close examination for three reasons: First, he developed his views as an immigrant/missionary in largely Christian societies, and often expressed them in dialogue with Christian priests and scholars. ${ }^{4}$ Second, his encounter with Christianity serves as the basis for the views adopted by his followers, who continue to increase in numbers today both within and outside India. Finally, the most oft-studied Hindu views of Jesus have been articulated by thinkers who tend to draw from neo-Vedantic or broadly non-dualist traditions. Prabhupāda, on the other hand, articulated his view of Jesus while remaining firmly committed to the theology and ecclesiastical authority of a specific Vaiṣnava sampradāya. This both set boundaries and opened up new possibilities for Prabhupāda's understanding of Jesus, as I hope will become apparent in the course of this short essay.

My project here will be rather limited in scope; I will not attempt to assess or even summarize the entirety of Prabhupāda's response to Christian traditions, a project which has yet to be done in a satisfactory manner. Here I will discuss only his understanding of Jesus, and that too in an abridged manner. In Prabhupāda's written and spoken teachings, we find nearly 1500 references to Jesus. In the vast majority of these instances, Jesus is also called
"Christ," and he receives the title "Lord" about a third of the time. While Prabhupāda did not attempt to develop a systematic Christology, there are nevertheless consistent themes that emerge in his understanding of Jesus. Here, I would like to focus on three facets of Prabhupāda's understanding of Jesus, in the following order. First, I will discuss his use of Jesus as the ideal example of a Vaiṣnava, a term which Prabhupāda employs to refer to anyone who worships a supreme personal Deity and situates themselves in a scriptural tradition. Second, I will examine Prabhupāda's understanding of redemption from sin through Jesus. And finally, I will address Prabhupāāda's view of Jesus' death and resurrection.

For followers of Caitanya, the Bhāgavata Purāna is the highest source of scriptural knowledge, for it tells of Krishna in a manner that is rich with both philosophy and emotion. Prabhupāda's life's work was his commentary on the Bhāgavata Purāna, which comprises some eighteen volumes of Sanskrit and English. A key verse from the third book, found in Kapila's teachings on sammkhya, describes the character of a saintly devotee of God, which Prabhupāda translates as follows: "The symptoms of a $s \bar{a} d h u$ are that he is tolerant, merciful and friendly to all living entities. He has no enemies, he is peaceful, he abides by the scriptures, and all his characteristics are sublime" $(3.25 .21) .^{5}$ Prabhupāda was fond of this verse and he quoted it often in his lectures. In his commentary, and when he discusses it in lectures, Prabhupāda offers Jesus as the ideal example of such a sādhu (730718bg.lon). He repeatedly points out Jesus' tolerance (titikșu) in the face of great suffering, his compassion (kārunika) toward those who crucified him, and his desire to do good for everyone (suhṛd). Prabhupāda even offers Jesus as an example of someone who had no enemies, for although the world is a "treacherous" place, a sādhu himself does not bear enmity toward anyone (660530bg.ny).

This admiration for the character of Jesus, however, is not seen merely in terms of personality traits, but is placed squarely in the context of Jesus' work and message. Indeed, it can be argued that Prabhupāda's strongest affinity for Jesus lay in the realm of mission. In 
his commentary on the Bhagavad-gitta, Prabhupāda writes,

There are many examples in history of devotees of the Lord who risked their lives for the spreading of God consciousness. The favorite example is Lord Jesus Christ. He was crucified by the nondevotees, but he sacrificed his life for spreading God consciousness. . . Similarly, in India also there are many examples, such as Thākura Haridāsa and Prahlāda Mahārāja. Why such risk? Because they wanted to spread Krṣna consciousness, and it is difficult. A Kṛ̣na conscious person knows that if a man is suffering it is due to his forgetfulness of his eternal relationship with Krṣna. Therefore, the highest benefit one can render to human society is relieving one's neighbor from all material problems (11.55). ${ }^{6}$

Prabhupāda frequently juxtaposes Jesus with Vaiṣnava saints such as Prahlāda, Nityānanda, Haridāsa, and even Buddha as examples of persons who suffered as a result of their persistence in practice and mission (710908sb.lon). Their persistence is described by Prabhupāda as a product of their compassion toward others' suffering (Bhāgavatam 11.2.5).

In theological terms, this benevolence is embodied by the guru or spiritual master. According to the eighteenth century Gaudiya theologian Viśvanātha Cakravartī, the guru's primary quality is compassion, which pours forth without discrimination like the monsoon rains (741219sb.bom). When the master initiates a disciple, he takes upon himself the disciple's past sins, wiping the karmic slate clean. In instances where the stock of bad karma is particularly large (because of the large number of disciples or their sinfulness), the guru may suffer for some of his disciples' karma. In a conversation with a disciple, Prabhupāda elaborates, "So to become a guru is not an easy task. You see? He has to take all the poisons and absorb [them]. . . . That idea is in Bible. Just like Jesus Christ took all the sinful reactions of all people and sacrificed his life. That is the responsibility of spiritual master." (720227ta.may). Thus the possibility of redemption through. Jesus Christ is never called into question by Prabhupāda, for he repeatedly affirms Christ's role as guru. In another conversation, he recalls: "Once, in Melbourne, a group of Christian ministers came to visit me. They asked, 'What is your idea of Jesus Christ?' I told them, 'He is our guru. He is preaching God consciousness, so he is our spiritual master." (Self-Realization 135-6). In his role as guru, Jesus is worthy of emulation by all Vaișnavas, but especially by those who have chosen discipleship in his sampradāya. In this regard, Prabhupāda was at times critical of Christians for making their guru suffer by continuing their sinful behavior and not following his teachings faithfully. "Christ can take the sufferings for the previous sins of his devotees. But first they have to be sane: 'Why should I put Jesus Christ into suffering for my sins? Let me stop my sinful activities." (SelfRealization 135).

Gurus who display extraordinary sacrifice and skill in service to God are regarded by Prabhupāda as saktyāveśa avatāras. In the extensive typology of avatāas found in Caitanya Vaiṣnava theology, saktyāveśas are distinct because they are not direct descents of God himself. They are rather human beings who have been invested with (or possessed by) an aspect of 'God's power, and so they display extraordinary influence as they go about their work. In Caitanya Vaișnava tradition, the travelling sage Nārada, the learned seers called Kumāras, and the historical Buddha are placed in this category. Prabhupāda explains that Jesus should also be regarded as a śaktyā veśa avatāra because he "preached" about the glorification of the Supreme Lord" and "sacrificed everything for preaching the glories of the Lord" (661231cc.ny). "We should not think of him as an ordinary human being" (Self-Realization 136).

Thus for Prabhupāda, redemption through Christ is primarily a result of discipleship, and Jesus' suffering is evidence of that redemption. His unbounded compassion led him to be extraordinarily liberal in inviting disciples, which resulted in his suffering on the cross. Jesus' death, however, is a different matter. Indeed, Prabhupāda held that Jesus' death was 
only apparent, and his argument was based largely on fundamental metaphysical assumptions held by Vaișnavas. The self is eternal and the material body always inert, and thus even ordinary persons do not die (740615rc.par). What we call death is merely a separation of the self from the body, but the very fact that Jesus reappeared in the same body is evidence that he did not die (690103bg.la). Prabhupāda offers two alternate possibilities: as an adept yogi, Jesus was skilled in maintaining life even with the vital signs absent (Bhāgavatam 7.3.18); or in more Docetic fashion, Jesus possessed a spiritual body that is eternal and indestructible (690103bg.la). In either case, Prabhupāda does not attempt to definitively resolve the question of Jesus' death and resurrection; for him the primary message of Christ's life is his suffering, and the kindness, forbearance, and courage that such a sacrifice requires.

As one would expect, Prabhupāda's preclusion of a real death for Jesus became a point of contention in his conversations with Christians. In these instances, Prabhupāda approached the argument in a manner typical to Vedāntic debate: he treated Christianity as he would an orthodox school of Indian philosophy, and Jesus as he would the founder of such a school. This accords Christianity the status of a valid system of practice, but also opens it up to questioning and debate based on shared interpretive assumptions and scriptural authority. In personal conversations, Prabhupāda often asked Christians to ground themselves firmly in their own scriptural tradition, thus recognizing it as valid source of knowledge, but he also did not hesitate to offer a critique based on his own scriptural sources.' In a lively conversation in Paris about Jesus' death, a guest disagrees with Prabhupāda at one point and says, "You cannot [deny this]. We accept the totality of the word, as you accept your word." Prabhupāda does not back down from his position, but instead quotes a verse from the Bhagavad-gītā, in effect asking her to accept the validity of his scripture.
Prabhupāda: "Died" means that is similar [to] death. Janma karma me divyam. ["My birth and action are divine."] . . .

Guest: No, it is very important that the death of Christ is a real death. For us, it is the center of our faith.

Prabhupāda: No according to Vedic conception, even ordinary living being, he does not die. Na hanyate hanyamāne sarīre . . . apparently, the body being dead, the soul is never dead. (740615rc.par)

There is little doubt that Prabhupāda's Jesus is a vaisnavized Jesus, understood in terms of Caitanya Vaișnava metaphysical assumptions and theological categories such as $\bar{a} t m \bar{a}, s \bar{a} d h u$, avatära, and guru. Yet it is also clear that Prabhupāda does not intend to subsume Jesus wholly within his own tradition, as yet another individual in a long list of gurus and avatāras. In a conversation on scriptural hermeneutics with Emmanuel Jungclaussen, a Benedictine monk of the Niederalteich Monastery in Bavaria, Prabhupāda concludes by saying, "I have not come to teach you, but only to request you to please chant the name of God. . . . If you simply chant the name of God found in your own scriptures, you will attain the spiritual platform." (Self Realization 131). "In all religions," Prabhupāda writes elsewhere, "temple worship and acceptance of authority are present. We may accept Kṛṣa, or Lord Jesus Christ, or Jehovah, or Lord Buddha, or Sarikarācārya, or Guru Nanak, but in any case acceptance of authority is required. In Bhagavad-gitā Lord Sri Krșna is accepted as the supreme authority." (Elevation $6)$.

There is a sense in Prabhupāda that religious traditions stand and fall together-if the validity of one is compromised, so it is for the others. As S.K. Ghose puts it in his biography of Caitanya, "If it is a fact that a Messiah was born in Judea nineteen hundred years ago, it seems not unreasonable to suppose that, in other places, other Messiahs might appear at periods of the history of the world, and in different localities. Thus the advent of Jesus Christ establishes the possibility of the divine character of Sree Gauranga; and, in the same way, the advent of 
Sree Gauranga establishes the possibility of the advent of Jesus Christ." (10).

\section{Notes}

${ }^{1}$ All quotations from Prabhupāda's letters, lectures, and conversations are drawn from the electronic anthology produced by the Bhaktivedanta Book Trust called The Complete Teachings. They are cited using the unique reference number assigned to each entry in the anthology (e.g., 730421mw.la). References to Prabhupāda's written works, such as his commentaries on the Bhagavad-gittā and Bhāgavata Purāna, are cited, as usual, by giving page or verse numbers.

2 See for example Prabhupāda's morning walk conversation on April 21, 1973: "We respected our professors like our fathers. The relationship between the student and the professors was very good. I had one Scottish professor, Dr. W.S. Urquhart. He was my nice friend. He was professor of philosophy, psychology. Later on he became vice-chancellor" (730421mw.la).

${ }^{3}$ The most extensive hagiography of Prabhupāda is Satsvarūpa dāsa Goswami's seven-volume Srīla Prabhupāda-Lìlāmrta.

${ }^{4}$ See for example his conversation with Cardinal Danielou in Paris, published in The Science of Self Realization (115).

${ }^{5}$ titikṣavaḥ kārunikaḥ suhṛdah sarva-dehinām ajāta-Satravaḥ sāntah sâdhavah sādhu-bhüșanāhạ

${ }^{6}$ The verse upon which Prabhupāda is commenting here occurs at the end of chapter eleven, after Krssna has shown Arjuna his cosmic form. Prabhupāda translates the verse as follows, "My dear Arjuna, he who engages in My pure devotional service, free from the contaminations of fruitive activities and mental speculation, he who works for $\mathrm{Me}$, who makes Me the supreme goal of his life, and who is friendly to every living being - he certainly comes to Me." Prabhupāda makes the above comment about Jesus while explaining the phrase "friendly to every living being."

Works Consulted

Chakravarti, Kshitish Chandra. Life of Sri Chaitanya. Calcutta: Nadiya Printing Works, 1897.

Ghose, Shishir Kumar. Lord Gauranga, or Salvation for All. vol. 1: 2nd ed. Calcutta: P.K. Ghose, 1907.

Goswami, Satsvarūpa dāsa. Śrīla PrabhupādaLìlāmrta: A Biography of His Divine Grace A.C. Bhaktivedanta Swami Prabhupāda. Los Angeles: Bhaktivedanta Book Trust, 1980.
Kennedy, Melville. The Chaitanya Movement: A Study of the Vaishnavism of Bengal. London: Oxford UP, 1925.

Malkovsky, Bradley. "Christ in Hinduism: Traditional Views and Recent Developments." Alternative Christs. Ed. Olav Hammer. Cambridge: Cambridge University Press, 2009. pp. 150-169.

Morrison, John. New Ideas in India During the Nineteenth Century: A Study of Social, Political, and Religious Developments. Edinburgh: George A. Morton, 1906.

Prabhupāda, A.C. Bhaktivedanta Swami. Bhagavadgitā As It Is. 2nd ed. Los Angeles: Bhaktivedanta Book Trust, 1983.

---. The Complete Teachings. Electronic database. version 2003.1. Bhaktivedanta Archives, 2003.

---. Elevation to Krșna Consciousness. New York: Bhaktivedanta Book Trust, 1973.

---. The Science of Self-Realization. Los Angeles: Bhaktivedanta Book Trust, 1968.

---. Śrimad Bhāgavatam. 18 vols. Los Angeles: Bhaktivedanta Book Trust; 1987.

Schmidt, Peter. Krishna Meets Jesus: A.C. Bhaktivedanta Swami Śrīla Prabhupāda's Interpretations and Conclusions about Christianity. Germany: Books on Demand $\mathrm{GmbH}, 2002$.

Sen, Rai Bahadur Dinesh Chandra. Chaitanya and His Age. Calcutta: U of Calcutta, 1922.

Sen, Keshub Chunder. Asia's Message to Europe: A lecture delivered on the fifty-third anniversary of the Brabmo Samaj. Calcutta: Bhidan Press, 1883. 